\title{
Assessment of Electoral Management and Democratization System in Nigeria: A Case of Independent National Electoral Commission (INEC)
}

\author{
Samuel C. Ugoh ${ }^{1}$ and Wilfred I. Ukpere ${ }^{2, *}$ \\ ${ }^{1}$ Department of Political Science, University of Lagos, Akoka, Yaba, Nigeria \\ ${ }^{2}$ Department of Industrial Psychology and People Management, Johannesburg Business School, College of \\ Business \& Economic, University of Johannesburg, South Africa
}

\begin{abstract}
Nigeria is a country in transition. Since election constitutes a vital ingredient of every participatory democracy, the electoral system therefore is very vital in a country still under transition. Democracy, often, is based on its interface with development. Thus, if democracy is practiced in a manner that accommodates majority of the populace, it has the capacity to jump start human development. In Nigeria, however, the system of democracy has been intercepted by illegitimate regimes over the years, and thereby undermining national development. The relationship between the democracy and development engendered debates over the years among scholars and policy makers. This paper therefore postulates that the electoral institution in Nigeria could be blamed for ushering illegitimate governments, owning to their failure to conduct free and fair elections. The paper concludes that a policy should be formulated to strengthen the electoral body, Independent National Electoral Commission (INEC) to make it truly independent in carrying out the mandate of the people.
\end{abstract}

Keywords: Legitimacy, development, democracy, policy makers.

\section{INTRODUCTION}

Nigeria has been a nation in transition towards democratic governance. In other words, it is a country working hard to abandon anti-democratic antecedents toward more democratic culture. Therefore, since election constitutes a vital ingredient of democracy, the national electoral management was constituted. In essence, the country's reform processes and policy initiatives were aimed at refining the electoral system (Jega, 2014). Broadly, democracy is based on its interface with development in a manner that establishes the possibility of democratic ethos in the quest for national development. It critically and pragmatically follows that if democracy is well practiced in manner that accommodates popular legitimacy, it has the capacity to accelerate human development.

The relationship between the two has engendered discussions down the years among scholars and policy makers. According to Diop (2007), these debates are predicated particularly upon the understanding that democracy and development are crucial of prosperous and equitable society.

Democratization is neither a swift nor a smoothsailing experience. Some social scientists argue that, it is a long and tortuous process, which takes place

*Address correspondence to this author at the Department of Industrial Psychology and People Management, Johannesburg Business School, College of Business \& Economic, University of Johannesburg, South Africa; Tel: +27735295587; Fax: +27-1-5594943; E-mail: wiukpere@uj.ac.za incrementally in the course of societies transiting from authoritarian control into a liberal state (Ninalowo, 1999). The Nigerian experience is a case in point. Before 1999, the country was in fits and starts, characterized by military intervention in the governance beginning from 1966 - 1975, from 1983 - 1985 and 1993 to 1998 respectively. However, from 1999 onwards, there has been some relative stability in the nation's polity. However, the issue of the democratization process being bedeviled by badly conducted elections seem to be frustrating Nigerians, resulting to disenchantment of the populace, prompting questions as to whether electoral democracy is still relevant and valid for Nigeria as a nation (Jega, 2014).

Elections are fundamental features of representative democracy. The country's Independent National Electoral Commission (INEC) is an institution established to conduct election in Nigeria. The institution is guided by the constitution to be independent in order to conduct free and fair elections. However, INEC has shown to the citizens that it is unable to conduct a free and fair election (Ugoh, 2004). Evidence has manifested in the series of elections conducted since 1999 to date. The main problem is that the present circumstance relating to the appointment of members and funding of the commission is faulty (Ugoh, 2004). In addition, the commission is corrupt and, as such, unable to conduct a credible election. In Nigeria, the struggle for political power can be likened to a warfare. This situation is 
best captured in the observation of Obasanjo, who noted that election in Nigeria is a 'do and die fair' (Obasanjo, 2011).

\section{RESEARCH OBJECTIVES}

The paper, seeks to examine the factors responsible for non-credibility and irregularities in electoral process in Nigeria. Another basic objective of this paper is to investigate the challenges confronting INEC as an institution. The paper will attempt to proffer solutions on how these challenges can be tackled as a way to make the institution a more credible one.

\section{Research Approach}

This paper is a conceptual paper. The data used in this paper were mainly obtained from secondary sources. Published and unpublished materials such as journal articles, textbooks, newspapers and conference papers were consulted in this work, as key sources of information. It is pertinent to mention that some INEC officials and top politicians were preliminarily consulted to obtain some information related to the subject matter. However, some challenges were faced during the data gathering stage, as most people did not perceive the research activity as directly affecting them, since there were no monetary benefits to them for participating in the study.

\section{Conceptual Clarifications}

Election plays a vital role in nation building, and is an indispensable component of democratic process. In Nigeria, however, evidence shows that there is almost a near collapse of democratic system as a direct consequence of botch elections and electoral processes. The failure can be linked to the institution in charge of the electoral process in Nigeria (Okanu, 2015). This could be attributable to the direct ties between the electoral institution and the management of the day. Nevertheless, the trustworthiness of the elections depends to a great extent on the competency of the nation's electoral institutions (Okanu, 2015).

According to Abu (2009), the term democracy is a system of government, where the supreme authority in a society is vested on the people through free and fair election. Also, Diop (2007), argued that democracy connotes, adequate and equal representation of the people, and since everyone cannot be in power, the electorate through elections, vote for their representative who they give power to represent them. From that angle, democracy reflects the true will of the people. Similarly, Ake (1996) argued that if democracy is to be understood as popular, the centrality of election to the selection of the managers of the state cannot be over emphasized. Election, therefore, is a device for occupying an office or post by the electorates. According to Ugoh (2004: 1640), election has always been the legitimate way of transferring power from one regime to another through the ballot box. While electoral system is referred to as the rules and regulation which governs the method of selecting office holders.

In terms of democratic consolidation, it refers to the internalization of democratic ethos, as well as the establishment of excellent democratic practices through a policy that has succeeded elsewhere during a democratic transition. In the book 'Transition without End', Diamond, et al. (1999: 13) observed that if transition to democracy is to be achieved and sustained, there is a need for a deeper transition which must connect prebendalism to real institutionalism. In the case of Nigeria, it requires wise and imaginative institutional designs with capable and powerful force and agencies to enforce them. Onuoha (2004) summarized the condition for democratic consolidation as accountability, transparency, participation, rule of law and good governance. Other factors necessary for a credible electoral process are judiciary, an independent electoral institutions and strong political culture.

The point here is that the quality and credibility of elections depended on the managerial competency and electoral institution. Therefore, electoral body should not only be independent, as well as transparent in the conduct of elections, but must also be perceived as such, and be trusted by all actors involved in the electoral process (SSAN, 2003). In addition, the body must be impartial and capable enough to execute the assigned constitutional duties with little or no financial constraints. In other words, without a strong political culture and competent administration, the conduct of credible elections would become a total fiasco.

\section{Brief Electoral History in Nigeria}

The elections in Nigeria have been an exercise in futility. It has witnessed fraudulent practices, corruption, violence, etc. In fact, the past efforts towards democratization of the country have collapsed due to perverted electoral processes (Okanu, 2015). The problem has been linked to attitude of the political elites and institutional failures of the various electoral bodies. 
Evidence shows that the electoral body is not independent of the executive (Oyesola, 2019). In fact, the electoral bodies in the political history of Nigeria are tied to the incumbent executive, thereby, making it very difficult for the electoral bodies to be truly independent in discharging their functions.

From the Electoral Commission of Nigeria (ECN) of the First Republic to the Independent National Electoral Commission (INEC) of the current republic, electoral commissions seem to have displayed nothing but gross incompetence in discharging the roles for which they were created.

It may not be wrong to say here that most of the post-independence elections in the country were held with bloodletting (Ugoh, 2004). The magnitude of the problem is such that one could conclude that organizing a hitch-free transition election is impossible. For example, Nigeria election in 1964/65 ended in military takeover of government. Another attempt was made in 1983, and it, again ended in violence and military takeover of government (Osaghae, 1998). After ten years, in 1993, the freest ever conducted election took place and, thus ended up in serous violence (Osaghae, 1998). With these antecedents, Nigeria approached the 1999 elections with lots of fear and apprehension. This fear heightened in 2003 against the backdrop of skepticisms and doubts in some quarters that all the previous years, brought one calamity or the other to the nation in 1963,1973,1983, 1993, etc. In order to avoid bloodletting and past political problems the present paper considered the honesty, competency and impartiality of the electoral body, INEC and the management of the democratization process in Nigeria.

\section{Electoral Institution and Democratization Process}

The General Sani Abacha's regime, which succeeded the Interim National Government, established the National Commission of Nigeria (NECON) to conduct a general election in Nigeria. However, the demise of General Abacha saw General Abdulalam Abubakar at the helm of affairs (Ugoh, 2004). He overhauled the electoral commission and established the Independent National Electoral Commission (INEC). This body came into existence with the enactment of Decree No. 17 of August 11, 1998. The commission's responsibility as contained in the 1999 Constitution is related to the totality of the electoral cycle which include provision of conducting credible elections, updating voters' register, the functioning of political parties, clearance of candidates, conducing party campaigns, conducting elections and speedy counting as well as declaration of results (INEC, 2006: 49). These objectives placed the electoral commission on a strategic position. In this regard, the success of an election is linked to the efficiency of this body. In Nigeria, evidence has shown that a noncompetent, partisan, bias and resource starved institution failed to midwife successful free, fair and credible elections. In other words, the nation has witnessed issues, where democratization has been bungled on the altar of poorly managed electoral process. According to Osaghae (1998) for example, the incompetency and partisanship that characterized the management of the general elections in 1964 and the 1965 western regional election contributed greatly to ensuing violence which truncated the first republic.

In addition, same tread was visible in 1979 and 1983 general elections. Of the entire crisis that emerged during the conduct of these elections, the most serious was the disorganized ways by which the voters' register was collected. In fact, most stakeholders called for the annulment of the whole registration activities and the termination of the duty of the commission's chairperson, Justice Ovie-Whiskey (Diamond, 2002). The aborted nature of the third republic attested to this point. The National Electoral Commission (NEC) set up by General Babangida did not endure due to the annulment of 1993 presidential election (Diamond, 2002).

Thus, owing to the fact that the foundation of a successful election is to have a credible voters' register, INEC took the initiative to undertake a comprehensive computer based voters' registration also known as Direct Data capture tech (DDC) before the 2011 general election (Adesina, 2006). The decision was to reduce to the barest minimum, the fraudulent activities and anomalies that characterized the manual registration system in Nigeria. This process saw INEC collecting data from voters' on its computers at selected registration points, storing them before issuing temporary voters' card. Evidences gathered were sorted, scanned and compiled into state voters' register list before being transferred to INEC headquarter (Adesina, 2006).

In spite of its novelty, the exercise was not without problems, as INEC experienced difficulties that led to people questioning its preparedness to use the computerized system of voters' registration as a policy to largely computer illiterate electorates (Punch, 2006). Apart from the challenge of insufficient machines for 
the registration, the exercise was followed by allegations of favoritism from parties in opposition. For example, the Conference of Nigerian Political Parties (CNPP) notably accused INEC of recruiting members of the ruling People's Democratic Party as temporary staff during the exercise (Punch, 2006: 9). More than that, the voter registration machines were found at the residences of Alhaji Lamidi Adedibu and the former state deputy Governor Otumba Alao Akala (Punch, 2007). This is an indication that some politicians were ready to use all it takes to undermine the electoral process. Moreover, by interfering with the issue of candidates that can vie for an elective post as opposed to their constitutional mandate indicated a clear image that the commission was a bias umpire (Punch, 2007). The previous denial of Vice President Atiku Abubakar by then President Obasanjo as PDP presidential candidate and possible successor to President Obasanjo attested to the point. Again, the woes of INEC was heightened by lack of financial autonomy as it depended on the executive for funding as well as the method of appointment of the INEC chairman and other key personnel (Oluokun, 2015). Such arrangement denies the commission autonomy and independence. However, the commission strived to cope with some of these challenges. Thus, before the 2015 general elections, INEC introduced the use of Permanent Voters' Card (PVC) and Card Readers for the elections. According to the body, the card reader is the first stage of the verification process of the identity of voters, while the PVC is to ascertain the genuineness of their voter card. However, the failure of these innovations in many areas of the country, forced the body to reverse back to the use of manual accreditation in most parts of the country (Oluokun, 2015). For example, the embarrassing failure of the device during former President Jonathan and his wife's turn to be accredited was the highest disappointment with the process (Oluokan, 2015).

Before this, there was a kind of people's apathy to collect the PVCs, because of the INEC's irregularity and improper distribution of the voters' card. Following the lapses, some state governments declared holidays to enable the people pick their PVCs. Another snare during the election is the issue of security. The activities of Boko Haram in the north-east zone created security challenges for a credible election in the area. For instance, four states and twenty-four local governments councils in the zone were not safe for elections as emergency rules was imposed (Okanu, 2015). In fact, about nineteen local governments in the zone were in control of the Boko Haram sect. Thus, the meeting of the National Council of State on the issue resulted in the postponement of the 2015 general elections for six weeks (Okanu, 2015). The INEC chairperson who announced the postponement cited the security situation in the country as the main reason. As expected, the postponement of the general elections attracted criticisms from the opposition parties as majority of them noted that it was a device by the then ruling party, Peoples Democratic Party (PDP) to rig the election. This fear was confirmed when President Goodluck Jonathan announced the use of the military during the elections. As the opposition parties were strengthening their strongholds, came the call for INEC chairperson to be removed by some members of the ruling party. They advise the president to appoint an Interim chairperson to conduct the elections as well as to do away with the use of PVCs and reader cards.

At this point, INEC announced that about $68,833,746$ million voters registered and 71 percent has picked up their PVCs. With this development, about 20 million people were disenfranchised from voting on the presidential election held on March 28, 2015. Indeed, the victory of the All Progressive Congress (APC) was a dream come true from the merged four political parties (Okanu, 2015).

With regards to the elections, in spite of the failure of the card readers and other logistic challenges, the Nigeria's electoral process seems to be inching towards perfection, reducing rigging and assuring the people the opportunity to vote out any bad government. According to the Nigerian Civil Society Organisation, in spite of the several operational and logistical lapses by the INEC, voters endured many difficulties at the polling stations. This pointed out some critical areas of challenges like late arrival of materials, delayed accreditation, and inadequate security agencies (Oluokun, 2015: 32). Similarly, the African Union Election Observers Mission (AUEOM) noted that Nigerians have demonstrated a peaceful democratic process. However, the Union was quick to identify some problems associated with the elections, which among others is the non-functional Permanent Voters Card in some areas. More than that, European Union Election Observation Mission (EU-ECOM) did not only agree with the AUECOM, but went further to identify the frustration and challenges of failing biometric voter verification, which led to re-polling the next day (Oluokun, 2015). In all, the elections were adjudged the best since the country's independence, which indicated improvement from the electoral body. 
However, looking at the 2019 general elections under a new INEC chairperson, Prof. Mahmood Yakubu, the situation still remained the same. It showed that the commission has not learnt from its past mistakes. Out of about 84 million registered voters, only 73 million were able to pick their PVCs. Thus, the Presidential and National Assembly elections were scheduled to hold on the $16^{\text {th }}$ February 2019 and $2^{\text {nd }}$ of March 2019 for the governorship and States' Houses of Assembly.

Suddenly, the INEC chairman who already had assured Nigerians that the commission was ready and prepared for the elections announced the postponement of the elections for another one week. The announcement, which came five hours and 15 minutes to the commencement of the election, was a rude shock not only to Nigerians but also to the international community (Onyekpere, 2019). The INEC chair cited logistical challenges as responsible for the development. Three things followed. Firstly, INEC was sued in more than 640 court cases and had 40 court orders to drop some candidates. Secondly, the bad weather was blamed for preventing INEC officials from flying election materials to certain locations. Thirdly, the commission was sabotaged as some of its offices in Anambra, Abia and Plateau States were set ablaze. Thus, the chairperson noted that the decision to postpone the election was entirely taken by the commission, and, assured everyone that it has nothing to do with political influence, or availability of sensitive materials or security issues (Onyekpere, 2019).

Regrettably, all the problems cited by INEC for postponing the elections were rudimentary, careless, overwhelming, provocative, insulting and silly. In fact, such could only happen in a country that lacks basic state capacity (Fasan, 2019). It should be mentioned here, that the postponement of the general elections has become a recurring feature of Nigeria's electoral process since the fourth republic. As expected, this postponement attracted criticisms from various stakeholders. For instance, Adams Oshiomhole, the National Chairman of the ruling party, APC, noted that the reasons given by INEC was disgusting, and thus, called for the resignation of the INCE chairman (Ugwu, et al., 2019: 6). In similar vein, the minister of state for transportation, the Nigerian Airspace Management Agency (NAMA) and the minister of state for Aviation debunked the claim that bad weather disrupted any flight (Adamolekun 2019).

Accordingly, Kareem Waheed noted that the APC government has failed Nigerians and called on the
INEC chairman to step down for playing out a game with the ruling party (Vanguard, 2019: 5). In a similar statement, the PDP National Publicity Secretary, Kola Ologbodiyan stated that the Buhari-led presidency and APC have been breathing down on the chairperson of INEC in a desperate and feverish bid to consolidate their control of the operations of the commission and execute its rigging plot (Oluyemi, 2019). In a related statement, Isa Saulawa, a PDP stalwart stated that it was an act of cowardice on the part of the APC and the government, because the commission acted on the dictates of the government and it was clear to the government that APC could not have won the election if it was held as scheduled. In addition, he maintained that the INEC was ready to conduct the elections but the APC was not ready. To him, the nature and method of appointment of the commission's chairperson showed that the Independent of the commission was not guaranteed. The INEC chairperson could not possibly have taken such a decision to postponement an election of this magnitude without consultation with the president who appointed him (Oyesola, et al., 2019: 2).

In another related case, the PDP National Chairman, Prince Uche Secondus, while accusing APC government of being behind the postponement of the elections urged the INEC to appoint external auditors to probe the organisation, Activate Technologies Limited. (ATL), a firm owned by the Niger-East Senatorial candidate of the APC, Mohammed Musa. According to him, the firm was allegedly given a contract by INEC to print permanent voter cards. This goes against both International and National conventions and electoral laws. He therefore, urged the commission to terminate the contract and cancelled the PVCs supplied by ATL, which have already been taken to 10 states and probably compromised to accept cloned PVCs (Fabiyi and Akinkuolu, 2019).

The Nigeria Labour Congress (NLC) also criticized the INEC action. In this regards, its chairman averred: "We joined other Nigerians in expressing our shock at the last minute postponement of the presidential and National Assembly elections. And no explanation will be good enough given INEC's repeated assurances to Nigerians" (Atoyebi, 2019).

Beyond politics, INEC action has a wide effect on the economy and on every individual. Indeed, the economy was shut down as business activities were grounded, schools were closed two days before the scheduled election dates and in some states public 
holidays was declared a day before and after the scheduled election. In fact, INEC rendered the entire day useless for nearly 200 million Nigerian citizens. No wonder, some have labeled the day as "a useless Saturday" for Nigerians (Kemhi, 2019: 18). In actual fact, the economy lost an estimated $\$ 300$ billion in revenues with a six months decline in the country's stock market. The International observers, who came to the country to monitor the election, were forced to pay extra cost to adjust their travelling arrangement (Oyesola, et al., 2019: 2).

Inexplicably, therefore, the postponement of the elections sullied the image of Nigeria as a nation in the eyes of the International community. Nigeria was liken to a giant that was not able to conduct as mere free, fair, peaceful and credible elections. Consequently, Nigerians may no longer stand tall amongst African countries to provide the much-needed leadership, which the nation was well recognized for. Besides, the country can no longer preach to other countries about the value of democracy or the important of conducting free, fair and credible elections in the continent. In fact, the decision has set the country backward in several ways. While other countries are moving forward, Nigeria seems to be treading backwards. Such outlooks are symptoms of significant institutional failure associated with countries that have severely weak state capacity.

Despite the logistical reasons for the postponement, the Presidential and National Assembly elections were held on $23^{\text {rd }}$ of February 2019. As expected, there were logistical failures ranging from delay in electoral materials, the malfunctioning of card readers, inadequate electoral materials and insecurity. In addition, incidence of electoral violence were reported in various parts of the country, notably in Rivers, Bayelsa, Lagos, Abia, Abuja, etc. The violence was reflected in the snatching of ballot boxes and burning of electoral materials in many parts of the country. INEC, however, announced the results in spite of these visible electoral irregularities. The APC presidential candidate was declared winner with $15,191,847$ votes against his closet rival, the PDP candidate, with 11,262,978. However, the PDP have not accepted the results and intend to challenge electoral outcome in court. It was observed that there were manifestations of premeditated malpractices in several states, which claimed about 25 lives (Onuegbu, 2019). The observers described the elections as a rape on democracy by desperate power mongers. Some sections expressed disappointment that the death toll was more than the 12 number of death recorded during the 2015 elections in the country. In fact, while voter turnout was roughly 44 percent in 2015, the 2019 presidential and National assembly elections slipped to 34.8 percent. Perhaps, this is the lowest since the history of general elections in Nigeria (Olukotun, 2019). This downswing may not be unrelated to the postponed elections and voters attribute in the electoral odyssey. In addition, the militarization of the electoral process was perceived as a disservice to the nation's nascent democracy, resulting in voter's apathy. In fact, a total of 1.6 million registered voters were disfranchised. In the same vein, INEC cancelled about 2.7 million votes without adequate reasons (Ugwu, 2019:6). However, in the face of all these aforementioned anomalies, the election was declared peaceful by INEC and some observers.

\section{SUGGESTIONS}

The work, which focused its lens on the challenges and issues confronting INEC in managing the democratization process, has tried to identify some of the problems. The suggestions towards solving these problems are as follows:

\section{Independent of the Electoral Commission}

There is a need to make the electoral body fully independent. The method of appointing the chairperson of the commission should come from the National Assembly. With this, the commission will be independent to discharge its constitutional duties without interference from the presidency or executive arm of government. The current appointment of the chairperson of the electoral body by the president signaled a doctrine and perception that a person can be a judge in his/her own case. This manner of appointment should be urgently addressed.

\section{Funding}

The funding of the body should not have political connotation cum inclination. Thus, there should be adequate funds for the body to provide enough materials in addition to solving other logistic problems that may arise before, during and after the elections.

\section{Training and Development of Staff}

There is a great need to train and develop INEC staff in order to ensure professionalism. It was observed that some of the INEC officers were involved in corruption, while many others were inexperience in 
using some of the electoral technologies. Therefore, training and development of staff members could help to address these challenges. Moreover, the use of adhoc staff has always created opportunity for fraud, thereby hindering free, fair and credible elections, which sullied INEC image. The situation can only change if permanent staff are well trained to monitor and handle the electoral processes.

\section{Security}

There is a need for the government to provide adequate security on or before the elections. This will not only give the voters the confidence that their votes will count but also protect the electorate and electoral staff. That will also curb the menace of ballot snatching and other irregularities associated with election malpractices. In fact, security has become an issue confronting effective management of electoral process in the country. This must be adequately addressed in future elections.

\section{Strong Institutions}

There is a need to build a strong political institution, which will help to address conflicts among parties and between contestants. The politicians should be taught not see election as a do or die affair. In line with that, the offices of governance should be made less attractive by slashing the remunerations and benefits associated with these offices.

\section{Addressing Corruption}

There is need to check the abuse of power by the political class who display money to woe top public officers. Both the military and judicial officers have become tools in the hands of these politicians by assisting them to rig elections and getting away with murder. The government should come up with a policy that limit the fund for the electoral campaigns as well as punish offenders.

It is the authors' believe that if all these suggestions are taken into consideration, the electoral body in Nigeria will be in a better position to conduct elections that is free, fair and credible.

\section{CONCLUSION}

The work has tried to explore the nature of the electoral body, INEC, in Nigeria and the reason for its inability to conduct free and fair elections. The study $x-$ rays the challenges and issues that undermined the electoral body. Evidence shows that none of the electoral bodies in Nigeria has conducted credible elections since independence, including INEC. The work briefly highlighted the chronological account of elections in Nigeria and issues leading to electoral rigging and pinpointed the flaws in the electoral act. Every effort by these electoral bodies to conduct free, fair and credible elections seem to have been thwarted by politicians and stakeholders who see the election as a do or die affairs. However, the constituted electoral management institution in this fourth republic is deploying all the necessary resources at its disposal towards minimizing electoral malpractices in Nigeria. The country must become an effective and capable state. Without that, it would continue to suffer huge embarrassment from institutional failures to already battered international image. Presently, the body requires a policy backing for total independent especially in the appointment of the chairperson in other to achieve its objectives and redeem its image.

\section{REFERENCES}

Adamoleku, Y. (2019). "INEC Failed Nigeria and Nigerians". Lagos: Vanguard Newspaper February 21.

Adeshina, T. (2006). "The Voters' Registration Exercise." Paper delivered by the Director Voters' Registry Directorate, Independent National Electoral Commission, Abuja at a one day seminar on the Academic Community and the 2007 General election', organized by Independent National Electoral Commission (INEC) at Hamdala Hotel, Kaduna dated November 29.

Atoyebi, O. (2019). "NLC Shocked at Election Postponement." Lagos: The Punch Newspaper, February 18.

Diamond, L. (2002)."Free and Fair?: The Administration and Conduct of the 1983 Nigerian Elections", in A.A. Adesanya, G.J. Idang (eds.) Nigerian Government and Politics, 1979 1983.Calabar: Wusen Publishers.

Diop, (2007). "Democracy: An Adaptable System Critical for development" .Development Qutrech, vol. 9 No. 3, Washington D.C.: World Bank Institute.

Fabiyi, O and Akinkuolu, E. (2019). "Probe PVCs Supplied by APC Candidate's Firm: Secondus Tells INEC". Lagos: The Punch Newspaper, February 18.

Fasan, O. (2019). "Poll Shifts in Nigeria: Its abject state failure" Lagos: Vanguard Newspaper, February, 21.

Independent National Electoral Commission (2006a).Voter Education Training Manual: Building Confidence in the Electoral System. Abuja: Independent National Electoral Commission. Independent National Electoral Commission (2006b). Revised Guidelines for the Registration of Voters, revision and Continuous Updating of the National Register of Voters. Abuja: Independent National Electoral Commission.

Jega, A. (2014). "Challenges of Fraud-Free Election under a Democracy. A Presentation at a public lecture/book launch by the Mustapha Akanbi Foundation (MAF) in Harm Kwara State dated March 12.

Jega, A. (2014). "Stakeholders and the Electoral Process in Nigeria: Review of 2011 Elections and Projections for 2015". A lecture delivered at sociology distinguished lecture 2014 and Annual Conference organized by Department of Sociology, Faculty of Social Sciences, University of Lagos dated August 21. 
Kemhi, J. (2019). "INEC and The Treachery of Election Postponement”. Lagos: The Punch Newspaper, February 18.

Ninalowo (ed.) (1999). Crisis of Legitimization: The State and Vested Interest. Lagos: Obaroh and Ogbinaka Publishers Ltd.

Okanu, E. (2015). "There was no election in 2015" Newswatch Times Newspaper. Lagos, 27 July.

Olukotun, A (2019) "Beyond the Presidential and National Assembly elections”, Lagos: The Punch Newspaper, Backpage.

Oluokun, A. (2015). "The Bad", The Agenda for President Buhari, The News Magazine. Lagos: Vol. 44, No. 12, April.

Onuegbu, C. "25 killed in presidential, National Assembly Elections Observers Lagos: Vanguard Newspaper, February 28

Onyekpere, E. (2019). "INEC and the Postponed Polls" Lagos: The Punch Newspaper, February, 18.

Osaghae, E. (1998). The Cripple Giant: Nigeria Since Independence. London: Hurst Publishers.
Oyesola, B. et al (2019). "Delayed Poll: Economy Losses Over \#300bn" Lagos: The Sun Newspaper, February, 19.

Punch Editorial (2006). CNPP, INEC Trade Words over Voter Registration, Saturday Punch Daily, Lagos: October 7.

Punch Editorial (2007), Voter registration in the Garrison, Saturday Punch Daily, Lagos: January, 27.

Social Science Academic of Nigeria (2003). Editorial Comments: A Clarion call for peaceful, free and fair elections in 2003, Nigerian Social Scientist, 6(1).

Ugoh, S.C. (2004). "Electoral Malpractice and Violence in the 2003 General Elections in Nigeria”, Unilag Journal of Politics, Vol. 1.

Ugwu, R. and Orji N. (2019) "I won't concede defeat, our mandate stolen - Atiku" Lagos: Daily Sun Newspaper, February 28,

Ugwu, R. et al (2019). "Aftermath of the Election Shift: Buhari Spits Fire". Lagos: Daily Sun Newspaper, February, 19.

Received on 30-04-2019

Accepted on 01-06-2019

Published on 07-08-2019

DOI: https://doi.org/10.6000/1929-7092.2019.08.40

(C) 2019 Ugoh and Ukpere; Licensee Lifescience Global.

This is an open access article licensed under the terms of the Creative Commons Attribution Non-Commercial License (http://creativecommons.org/licenses/by-nc/3.0/) which permits unrestricted, non-commercial use, distribution and reproduction in any medium, provided the work is properly cited. 